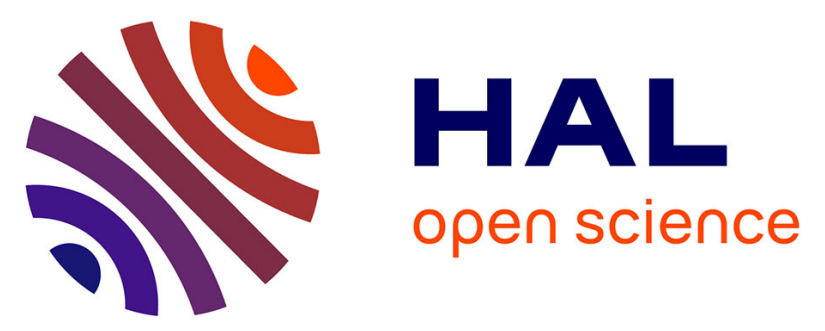

\title{
Comparative Study of Eleven Mechanical Pretreatment Protocols for Cryptosporidium parvum DNA Extraction from Stool Samples
}

Laure Claudel, Nicolas Valeix, Louise Basmaciyan, Bruno Pereira, Damien Costa, Anne Vincent, Stéphane Valot, Loic Favennec, Frederic Dalle

\section{To cite this version:}

Laure Claudel, Nicolas Valeix, Louise Basmaciyan, Bruno Pereira, Damien Costa, et al.. Comparative Study of Eleven Mechanical Pretreatment Protocols for Cryptosporidium parvum DNA Extraction from Stool Samples. Microorganisms, 2021, 9 (2), pp.297. 10.3390/microorganisms9020297 . hal03152180

\section{HAL Id: hal-03152180 \\ https://hal.univ-reims.fr/hal-03152180}

Submitted on 25 Feb 2021

HAL is a multi-disciplinary open access archive for the deposit and dissemination of scientific research documents, whether they are published or not. The documents may come from teaching and research institutions in France or abroad, or from public or private research centers.
L'archive ouverte pluridisciplinaire HAL, est destinée au dépôt et à la diffusion de documents scientifiques de niveau recherche, publiés ou non, émanant des établissements d'enseignement et de recherche français ou étrangers, des laboratoires publics ou privés. 


\title{
Comparative Study of Eleven Mechanical Pretreatment Protocols for Cryptosporidium paroum DNA Extraction from Stool Samples
}

\author{
Laure Claudel ${ }^{1}$, Nicolas Valeix ${ }^{1}$, Louise Basmaciyan ${ }^{1,2}{ }^{(D}$, Bruno Pereira ${ }^{3} \mathbb{D}^{D}$, Damien Costa ${ }^{4,5}$, Anne Vincent ${ }^{1}$, \\ Stéphane Valot ${ }^{1}$, Loic Favennec ${ }^{3,4}$ and Frederic Dalle ${ }^{1,2, *}$ \\ 1 Laboratoire de Parasitologie-Mycologie, Plateforme de Biologie Hospitalo-Universitaire, 2 rue A. Ducoudray, \\ BP 37013, CEDEX, 21070 Dijon, France; laure.claudel@chu-dijon.fr (L.C.); nicolas.valeix@chu-dijon.fr (N.V.); \\ louise.basmaciyan@chu-dijon.fr (L.B.); anne.lamy@chu-dijon.fr (A.V.); stephane.valot@chu-dijon.fr (S.V.) \\ 2 UMR PAM Univ Bourgogne Franche-Comté-AgroSup Dijon-Equipe Vin, Aliment, Microbiologie, Stress, \\ CEDEX, 21078 Dijon, France \\ 3 Unité de Biostatistiques, Direction de la Recherche Clinique (DRCI), CHU de Clermont-Ferrand, \\ 63000 Clermont-Ferrand, France; bpereira@chu-clermontferrand.fr (B.P.); loic.favennec@chu-rouen.fr (L.F.) \\ 4 Laboratoire de Parasitologie-Mycologie, Centre Hospitalo-Universitaire C. Nicolle de Rouen, \\ 76000 Rouen, France; damien.costa@chu-rouen.fr \\ 5 Centre National de Référence-Laboratoire Expert des Cryptosporidioses, Institut de Biologie Clinique, Centre \\ Hospitalo-Universitaire C. Nicolle de Rouen, 76000 Rouen, France \\ * Correspondence: frederic.dalle@chu-dijon.fr; Tel.: +33-(0)380295014
}

\section{check for} updates

Citation: Claudel, L.; Valeix, N.; Basmaciyan, L.; Pereira, B.; Costa, D.; Vincent, A.; Valot, S.; Favennec, L.; Dalle, F. Comparative Study of Eleven Mechanical Pretreatment Protocols for Cryptosporidium parvum DNA Extraction from Stool Samples. Microorganisms 2021, 9, 297. https:// doi.org/10.3390/microorganisms 9020297

Academic Editor: Todd

Riley Callaway

Received: 29 December 2020

Accepted: 26 January 2021

Published: 2 February 2021

Publisher's Note: MDPI stays neutral with regard to jurisdictional claims in published maps and institutional affiliations.

Copyright: (c) 2021 by the authors. Licensee MDPI, Basel, Switzerland. This article is an open access article distributed under the terms and conditions of the Creative Commons Attribution (CC BY) license (https:// creativecommons.org/licenses/by/ $4.0 /)$.

\begin{abstract}
Nowadays, many commercial kits allow the polymerase chain reaction (PCR) detection of Cryptosporidium deoxyribonucleic acid (DNA) in stool samples, the efficiency of which relies on the extraction method used. Mechanical pretreatment of the stools using grinding beads has been reported to greatly improve this extraction step. However, optimization of this key step remains to be carried out. Indeed, many parameters could influence the pretreatment performances, among which the modulation of the speed and duration of the grinding step, in addition to the physicochemical features of the grinding beads, have never been evaluated to date. In this study, eleven commercial mechanical pretreatment matrixes (Lysis matrix tubes ${ }^{\circledR}$, MP Biomedical, Irvine, CA, USA) composed of beads with different sizes, shapes, and molecular compositions, were evaluated for their performances in improving Cryptosporidium parvum oocyst DNA extraction before amplification by using our routinely used real-time PCR method. As expected, the eleven commercial mechanical pretreatment matrixes showed varying performances depending on the composition, size, and shape. All in all, the best performances were obtained when using the Lysing matrix, including ceramic beads with a median size (diameter of $1.4 \mathrm{~mm}$ ).
\end{abstract}

Keywords: Cryptosporidium parvum; mechanical pretreatment; DNA extraction; stool samples; real-time PCR; molecular diagnosis

\section{Introduction}

Cryptosporidium sp. is a protozoan parasite of medical and veterinary importance that causes gastroenteritis in a variety of vertebrate hosts, including humans. Transmission occurs through the fecal-oral route, by the ingestion of viable oocysts excreted in the environment by infected hosts. Because of their directly contaminating feature, ingestion of drinking water or food contaminated by Cryptosporidium oocysts can lead to epidemics affecting numerous people. In healthy subjects, cryptosporidiosis is asymptomatic or expresses as a diarrhea most often self-resolving. However, severe and prolonged infections are observed in immunocompromised patients and children under five [1,2]. The most frequent species isolated in humans are C. parvum and C. hominis, encompassing more than $90 \%$ of the cases of human cryptosporidiosis diagnosed in France [3]. Because treatment 
options remain limited, infection prevention and control measures are critical for the protection of vulnerable populations [4]. Thus, efficient diagnostic tools are needed for Cryptosporidium sp. detection in stool specimens from patients presenting with severe infection, as well as from asymptomatic carriers.

Nowadays, molecular diagnosis methods for the detection of Cryptosporidium sp. in stool samples are increasingly replacing microscopic techniques, and are sensitive, specific, and less time-consuming [5-8]. Molecular methods are multi-step procedures (including a pretreatment step, DNA extraction and amplification, detection of amplified PCR products. and data analysis), each step influenced by various parameters that need to be properly optimized. Some studies have already evaluated the performances of manual and automated systems for Cryptosporidium sp. DNA extraction from oocysts in stools [9-14]. However, the Cryptosporidium oocyst wall is a robust thick structure, composed of three distinct layers that combine to protect the internal sporozoïtes, and is also responsible for difficulties in extracting DNA by conventional methods [15-17]. Consequently, a pretreatment step aimed at disrupting the oocyst cell wall and facilitating the release of DNA for its further extraction needs to be adapted. To improve the extraction yield, several pretreatment protocols have been proposed, based on thermal (cycles of freeze-thawing) [18], chemical (i.e., reducing agents, lytic enzymes), or mechanical (i.e., blade or pestle, ultrasonication, pressure cell, bead beating) disruption of the oocysts [19]. However, recent studies have reported the highest performances of the mechanical pretreatment using grinding beads for DNA extraction from Cryptosporidium sp. oocysts [9,10].

In this context, we recently evaluated six extraction protocols associated with various mechanical pretreatments for C. parvum oocyst DNA extraction in a multicenter comparative study [20]. This study highlighted the importance of sample pretreatment, as well as the extraction method, to improve the diagnostic performances of $C$. parvum DNA amplification methods. More precisely, it has been demonstrated that the automated extraction systems, using Boom technology associated with mechanical pretreatment using grinding beads, present the best performance for Cryptosporidium DNA extraction.

Nowadays, pretreatment protocols use mostly silica beads or glass beads for the grinding sample. However, no consensus of use according to bead type is clearly specified in the scientific literature or by manufacturers. Therefore, knowing that (i) the mechanical pretreatment has been proven to improve DNA extraction from Cryptosporidium oocysts [9,10], (ii) the speed and duration features of the grinding step influence extraction performances, and (iii) most manufacturers do not provide technical recommendations for the mechanical pretreatment to improve DNA extraction from Cryptosporidium sp., routine practices vary between laboratories, and discrepancies exist in the PCR detection performances of Cryptosporidium sp. DNA. Thus, in order to go further in Cryptosporidium sp. DNA extraction protocol optimization, the aim of this complementary study was to evaluate the impact of the physicochemical parameters of the grinding beads used in the mechanical pretreatment on Cryptosporidium sp. DNA extraction performances.

\section{Materials and Methods}

This study was conducted between 27 July to 5 September 2020 at the parasitology laboratory of the University Hospital of Dijon, which has proficiencies in the molecular detection of Cryptosporidum sp. DNA from stools. The step-by-step protocol is detailed in Figure 1.

\subsection{Design of the Study}

In order to study the impact of the physicochemical parameters of the grinding beads for C. parvum DNA extraction and DNA amplification, eleven mechanical lysis matrixes were tested. As a reminder, a mechanical lysis matrix is a matrix composed of beads and/or particles of variable sizes, shapes, and chemical compositions, used for mechanical pretreatment. All in all, four stool samples with concentrations of oocysts ranging from 0 to 100 oocysts $/ \mathrm{mL}$ were tested per mechanical lysis matrix. The performances of the 
mechanical lysis matrixes were first evaluated by comparing the average percentage of positive Cryptosporidium paroum PCRs over the total number of PCRs performed at each C. parvum oocysts concentration for each mechanical lysis matrix, as described by Cha et al., 2014 [21].

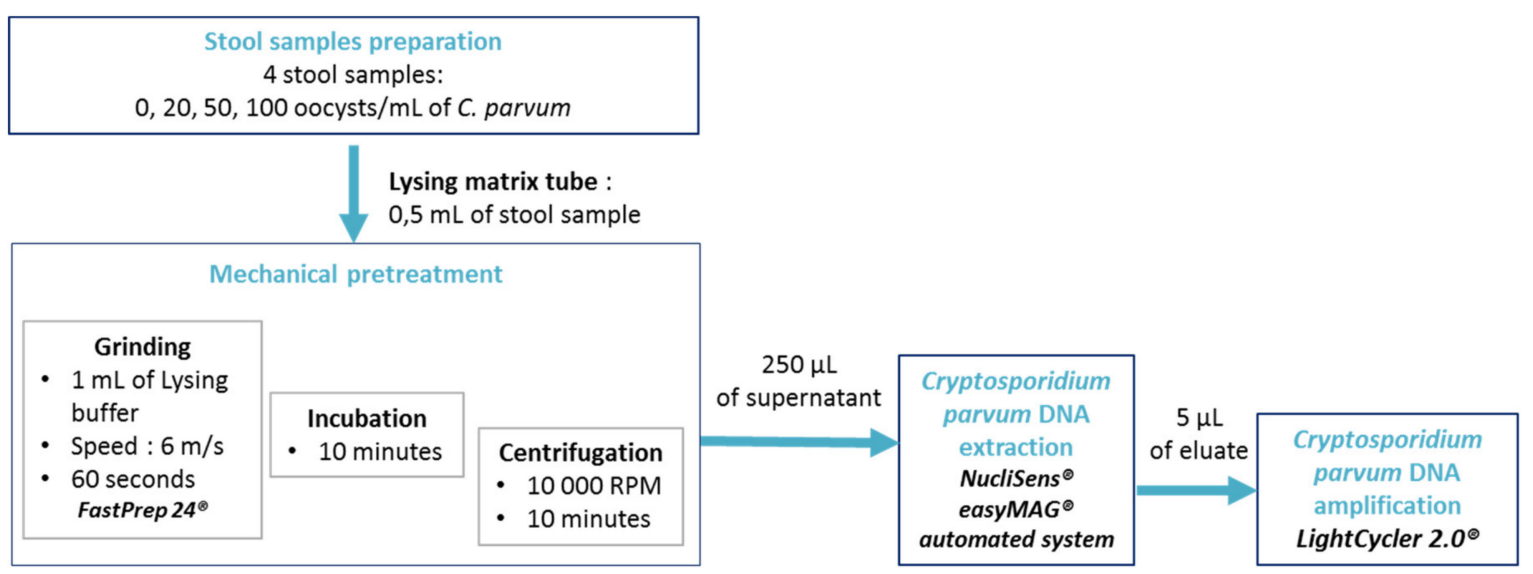

Figure 1. Experimental protocol flow chart (RPM: revolution per minute).

\subsection{Stool Samples Preparation}

The CNR-LE for cryptosporidiosis (University Hospital of Rouen, Rouen, France) provided oocysts of C. parvum subtype IIaA15G2R1 from diarrheal stools of young calves. In order to evaluate the impact of the physicochemical parameters of the grinding beads for C. parvum DNA extraction and DNA amplification, four stool samples with various concentration of $C$. parvum sp. oocysts were prepared using human feces negative as a matrix (i.e., negative human feces for (i) common digestive parasites by microscopy and (ii) for Cryptosporidium sp., Entamoeba sp., Giardia duodenalis, Enterocytozoon bieneusii, and Encaphalitozoon intestinalis by PCR methods). Type 7 stools, according to the Bristol Stool Form Scale (BSFS), were prepared from this stool according to the following protocol: $20 \mathrm{~g}$ of stool in $50 \mathrm{~mL}$ of physiological saline $(0.09 \% \mathrm{NaCl})$, filtered through a large mesh strainer and stored at $4{ }^{\circ} \mathrm{C}$. The number of DNA extractions varied with the parasite concentration tested, and was higher for the lowest concentrations to fit Poisson's law (a maximum of five extractions was carried out at the 10 oocysts $/ \mathrm{mL}$ concentration) (Table 1$)$. For each of the mechanical lysis matrixes tested, 10 stool samples containing $0(n=1), 20(n=5)$, $50(n=2)$, and $100(n=2)$ oocysts $/ \mathrm{mL}$ were prepared. The stool samples were stored at $4{ }^{\circ} \mathrm{C}$ until the experiment.

Table 1. Design of the study: the number of DNA extractions and Cryptosporidium-specific PCRs according to the parasite concentration for each of the grinding matrixes tested.

\begin{tabular}{cccc}
\hline \multirow{2}{*}{$\begin{array}{c}\text { Stool Concentration } \\
\text { (Oocysts/mL) }\end{array}$} & $\begin{array}{c}\text { No. of Extractions } \\
\text { Done per Method }\end{array}$ & \multicolumn{2}{c}{ No. of Cryptosporidium-Specific PCRs } \\
\cline { 3 - 4 } & 1 & per Extraction & Total \\
\hline 0 & 5 & 1 & 1 \\
\hline 10 & 2 & 6 & 30 \\
\hline 50 & 2 & 6 & 12 \\
\hline 100 & 10 & - & 55 \\
\hline All & & &
\end{tabular}




\subsection{Mechanical Pretreatment}

The eleven mechanical lysis matrixes tested in this study were composed of beads with different sizes, shapes, and molecular compositions, which relied on two important parameters of each matrix: the hardness and the density (Table 2). These eleven mechanical lysis matrixes can be divided into three distinct groups according to their chemical composition: (a) glass or silica, (b) garnet, and (c) technical ceramic (i.e., zirconium stabilized with cerium oxide, aluminum oxide, silicon carbide, yellow zirconium, and zirconium silicate). Mechanical grinding was carried out by applying the following protocol: $0.5 \mathrm{~mL}$ of stool sample was added to each of the mechanical lysis matrixes with $1 \mathrm{~mL}$ of NucliSens ${ }^{\circledR}$ lysing buffer before being grounded using the FastPrep $24^{\circledR}$ grinder/homogenizer (MP Biomedical, Irvine, CA, USA) at a speed of $6.0 \mathrm{~m} / \mathrm{s}$ for $60 \mathrm{~s}$, offering the best performances for Cryptosporidium sp. DNA, as reported by Valeix et al. [20].

\subsection{Cryptosporidium parvum DNA Extraction}

Cryptosporidium paroum DNA was extracted with the NucliSENS ${ }^{\circledR}$ easyMAG ${ }^{\circledR}$ automated system (BioMérieux, Marcy-l'Etoile, France) following the protocol by Jeddi et al., 2013 [10]. Briefly, after the mechanical grinding step, the stool suspension obtained was then incubated at room temperature for $10 \mathrm{~min}$ before being centrifuged at $10,000 \mathrm{~g}$ for $10 \mathrm{~min}$. Finally, $250 \mu \mathrm{L}$ of supernatant was transferred in the DNA extraction NucliSENS $^{\circledR}$ easyMAG ${ }^{\circledR}$ automated system (BioMérieux, Marcy-l'Etoile, France) with $50 \mu \mathrm{L}$ of NucliSENS ${ }^{\circledR}$ EasyMAG ${ }^{\circledR}$ magnetic silica (Biomérieux, Marcy-l'Etoile, France). Elution was performed at RT with $100 \mu \mathrm{L}$ of elution buffer. The eluted DNA volume obtained $(100 \mu \mathrm{L})$ was then stored at $4{ }^{\circ} \mathrm{C}$. PCR amplification was then performed within 10 days after DNA extraction.

\subsection{Cryptosporidium parvum DNA Amplification}

For Cryptosporidium parvum DNA amplification, our in-house PCR was used following the protocol as described in Brunet et al., 2016 [22]. Briefly, the amplification of a 258-bp DNA fragment located in the $18 \mathrm{~S}$ ribosomal ribonucleic acid (rRNA) gene (GenBank accession $n^{\circ}$ L16996; positions 80 to 337) was carried out using the forward $5^{\prime}$ GTT AAA CTG CRA ATG GCT 3' (Cry80F3) and reverse 5' CGT CAT TGC CAC GGT A 3' (Cry337R) primers, using the hybridization probes: $5^{\prime}$ CCG TCT AAA GCT GAT AGG TCA GAA ACT TGA ATG $3^{\prime}$ Fluorescein (anchor probe) and $5^{\prime}$ Red 640-GTC ACA TTA ATT GTG ATC CGT AAA G 34 Phosphate (sensor probe). Primers and probes were used at a concentration of $10 \mu \mathrm{M}$. Five microliters of DNA extracts were added to a final reaction volume of $20 \mu \mathrm{L}$ to each amplification reaction tube. Thermocycling and fluorescence detection were performed on the LightCycler 2.0 Roche Molecular Systems, Inc. (Rotkreuz, Switzerland). One negative (i.e., sterile water or stool samples without Cryptosporidium oocysts and other parasites) and one positive (i.e., stool samples containing C. parvum at the concentration of 100 oocysts $/ \mathrm{mL}$ ) controls were included in each assay. All in all, a total of 625 PCRs were carried out, including 605 Cryptosporidium-specific PCRs for Cryptosporidium DNA detection in stool extracts, and 20 PCRs for the internal control detection in stool extracts.

\subsection{Statistical Analysis}

The statistical analyses were performed using the BioStaTGV and GraphPad PRISM softwares. The PCR detection percentages with the different mechanical lysis matrixes were compared using the chi-square test. In case of small sample sizes, Fisher's exact test was used. The $\mathrm{Ct}$ values found by PCR were compared among the different mechanical lysis matrixes using the Kruskal-Wallis test, followed when appropriate (omnibus $p$-value less than 0.05 ) by Dunn's two-by-two post hoc test. A probability of 0.05 or less was considered to be significant. 
Table 2. The composition and properties of the mechanical lysis matrixes according to data from the manufacturer (MP Biomedical $\left.{ }^{\circledR}\right)$ HV: hardness according to the Vickers scale.

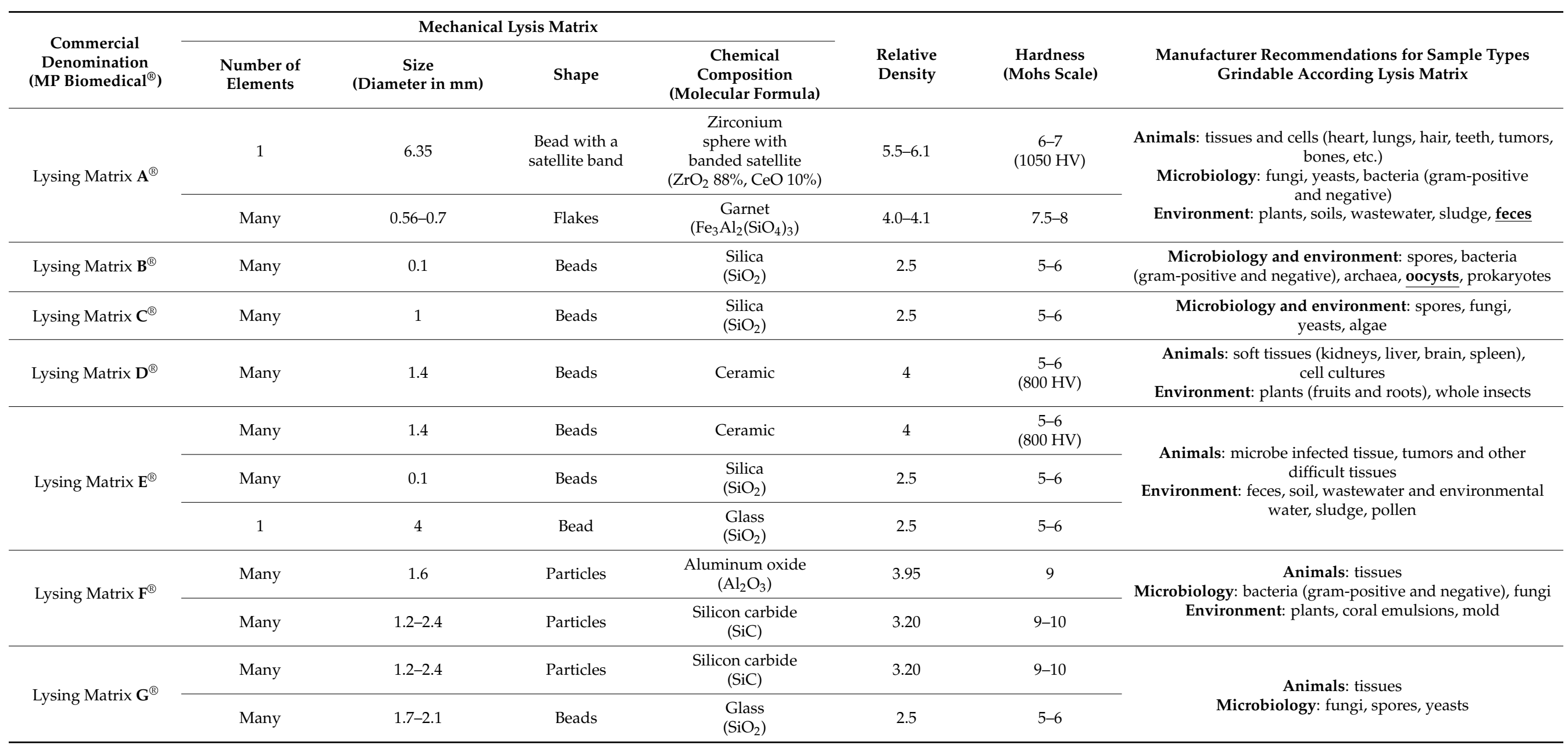


Table 2. Cont.

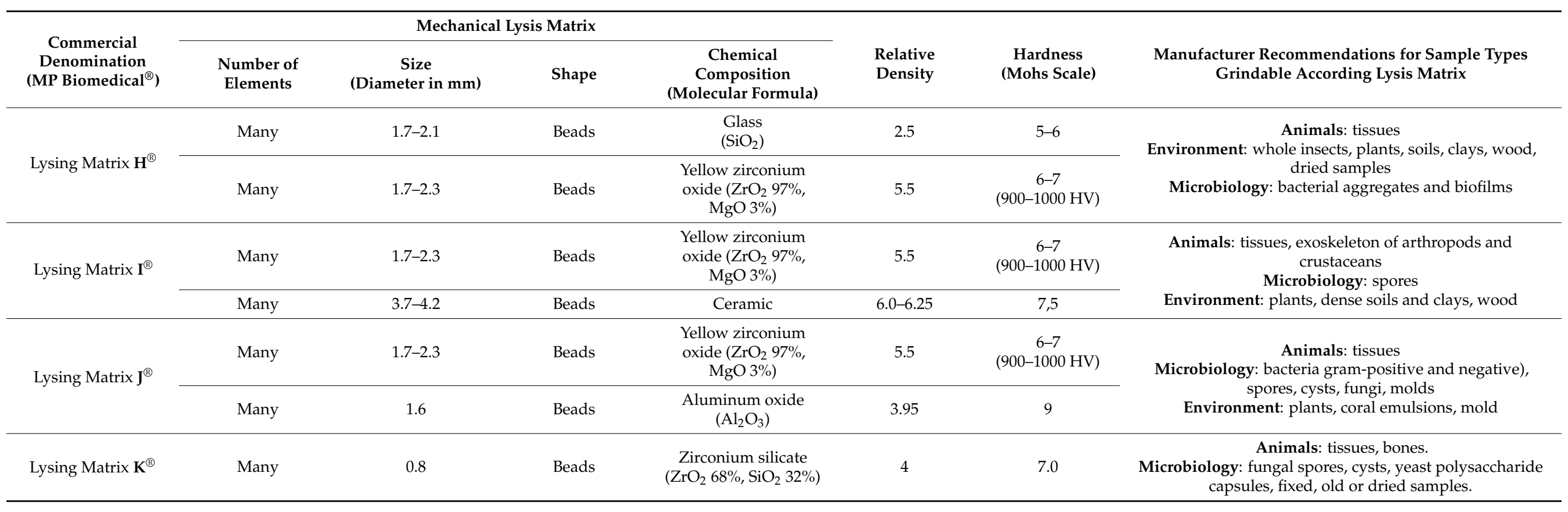




\section{Results}

\subsection{Influence of Mechanical Lysis Matrixes for Cryptosporidium parvum DNA Amplification}

All of the negative controls included in the study were negative by PCR. For the positive samples, the performances in C. parvum DNA amplification were variable depending on the mechanical lysis matrix tested. Globally, Lysing Matrix $\mathrm{D}^{\circledR}$ showed the best performances, with an average positive rate of $94.4 \%$. Oppositely, Lysing Matrix $\mathrm{B}^{\circledR}$ and Lysing Matrix $\mathrm{C}^{\circledR}$ had the lowest performances, with average positive rates of 64.8 and $53.7 \%$, respectively. The other mechanical lysis matrixes included in this study displayed acceptable performances, with average positivity rates ranging from $79.6 \%$ to 90.7\% (Table 3).

Table 3. Performances of the eleven mechanical lysis matrixes studied for Cryptosporidium parvum DNA extraction and amplification.

\begin{tabular}{|c|c|c|c|c|c|c|c|c|c|c|c|c|}
\hline \multicolumn{2}{|c|}{ Lysing Matrix ${ }^{\circledR}$} & A & B & $\mathrm{C}$ & D & E & $\mathbf{F}$ & G & $\mathbf{H}$ & I & $\mathbf{J}$ & $\mathbf{K}$ \\
\hline \multicolumn{2}{|c|}{ Overall Proportion of Positive Samples (\%) } & 83.3 & 64.8 & 53.7 & 94.4 & 88.9 & 90.7 & 87.0 & 79.6 & 83.3 & 87.0 & 85.2 \\
\hline \multirow{3}{*}{$\begin{array}{l}\text { Proportion of Positive } \\
\text { Samples at Each } \\
\text { Concentration (\%) }\end{array}$} & 20 oocysts $/ \mathrm{mL}$ & 70.0 & 40.0 & 26.7 & 90.0 & 80.0 & 83.3 & 76.7 & 63.6 & 70.0 & 76.7 & 73.3 \\
\hline & 50 oocysts $/ \mathrm{mL}$ & 100 & 91.7 & 75.0 & 100 & 100 & 100 & 100 & 100 & 100 & 100 & 100 \\
\hline & 100 oocysts $/ \mathrm{mL}$ & 100 & 100 & 100 & 100 & 100 & 100 & 100 & 100 & 100 & 100 & 100 \\
\hline
\end{tabular}

When analyzing the results depending on the C. parvum oocyst concentration, significant differences were observed at the concentration of 20 oocysts $/ \mathrm{mL}$ between the eleven mechanical lysis matrixes studied, with the positive rate varying from 26.7 to $90.0 \%$ (Tables 3 and 4 ). More precisely, at the concentration of 20 oocysts $/ \mathrm{mL}$, Lysing Matrix $\mathrm{B}^{\circledR}$ and Lysing Matrix $C^{\circledR}$ showed the lowest performances, with positive rates of 40.0 and $26.7 \%$, respectively. The other nine Lysing Matrix (i.e., $\mathrm{A}^{\circledR}, \mathrm{D}^{\circledR}, \mathrm{E}^{\circledR}, \mathrm{F}^{\circledR}, \mathrm{G}^{\circledR}, \mathrm{H}^{\circledR}, \mathrm{I}^{\circledR}, \mathrm{J}^{\circledR}$, and $\mathrm{K}^{\circledR}$ ) showed comparable results for this concentration, with positive rate varying from $63.3 \%$ to $90 \%$ (Table 3 and Table S1). Finally, the eleven mechanical lysis matrixes showed no significant differences at concentrations of 50 and 100 oocysts/mL (Table 3).

Table 4. Average of Ct values and standard deviations of PCR results according to the mechanical lysing matrix and oocyst concentration.

\begin{tabular}{|c|c|c|c|c|c|c|c|c|c|c|c|c|}
\hline & & \multicolumn{11}{|c|}{ Lysing Matrix } \\
\hline & & $\mathbf{A}$ & B & $\mathrm{C}$ & $\mathbf{D}$ & $\mathrm{E}$ & $\mathbf{F}$ & G & $\mathbf{H}$ & $\mathbf{I}$ & $\mathbf{J}$ & $\mathbf{K}$ \\
\hline \multirow{3}{*}{$\begin{array}{c}\text { Average of } \\
\text { Ct Values } \\
\pm \\
\text { Standard } \\
\text { Deviation }\end{array}$} & 100 oocysts /mL & $\begin{array}{l}34.68 \\
\pm 0.57\end{array}$ & $\begin{array}{l}35.23 \\
\pm 1.34\end{array}$ & $\begin{array}{l}35.67 \\
\pm 2.54\end{array}$ & $\begin{array}{c}33.58 \\
\pm 0.45\end{array}$ & $\begin{array}{c}33.71 \\
\pm 0.62\end{array}$ & $\begin{array}{c}34.74 \\
\pm 0.77\end{array}$ & $\begin{array}{l}34.55 \\
\pm 1.23\end{array}$ & $\begin{array}{l}35.03 \\
\pm 0.43\end{array}$ & $\begin{array}{c}34.72 \\
\pm 0.45\end{array}$ & $\begin{array}{l}34.78 \\
\pm 0.78\end{array}$ & $\begin{array}{l}34.62 \\
\pm 0.57\end{array}$ \\
\hline & 50 oocysts $/ \mathrm{mL}$ & $\begin{array}{c}35.84 \\
\pm 1.18\end{array}$ & $\begin{array}{l}38.07 \\
\pm 3.04\end{array}$ & $\begin{array}{l}37.91 \\
\pm 4.31\end{array}$ & $\begin{array}{c}34.74 \\
\pm 1.42\end{array}$ & $\begin{array}{l}34.38 \\
\pm 1.03\end{array}$ & $\begin{array}{l}35.59 \\
\pm 0.75\end{array}$ & $\begin{array}{c}36.13 \\
\pm 1.01\end{array}$ & $\begin{array}{c}35.94 \\
\pm 0.59\end{array}$ & $\begin{array}{l}35.06 \\
\pm 0.74\end{array}$ & $\begin{array}{l}35.85 \\
\pm 1.52\end{array}$ & $\begin{array}{l}35.75 \\
\pm 0.71\end{array}$ \\
\hline & 20 oocysts $/ \mathrm{mL}$ & $\begin{array}{l}39.12 \\
\pm 4.15\end{array}$ & $\begin{array}{l}42.25 \\
\pm 3.81\end{array}$ & $\begin{array}{l}43.53 \\
\pm 2.85\end{array}$ & $\begin{array}{l}37.47 \\
\pm 3.20\end{array}$ & $\begin{array}{l}38.05 \\
\pm 4.16\end{array}$ & $\begin{array}{l}39.27 \\
\pm 3.51\end{array}$ & $\begin{array}{l}39.40 \\
\pm 3.71\end{array}$ & $\begin{array}{l}40.15 \\
\pm 4.14\end{array}$ & $\begin{array}{c}40.11 \\
\pm 3.76\end{array}$ & $\begin{array}{l}39.22 \\
\pm 3.52\end{array}$ & $\begin{array}{l}39.28 \\
\pm 3.84\end{array}$ \\
\hline
\end{tabular}

3.2. Influence of Mechanical Lysis Matrixes on the Average Cycle Threshold (Ct) Values Obtained during Cryptosporidium parvum DNA Amplification by PCR

The average cycle threshold $(\mathrm{Ct})$ obtained for the external control was $33 \mathrm{Ct}$, with a standard deviation of 0.80 . For the spiked samples, the specificity was confirmed with the melting curve (i.e., melting temperature (Tm) of $53.5^{\circ} \mathrm{C}$ for C. parvum). All in all, Lysing Matrix $\mathrm{D}^{\circledR}$ and Lysing Matrix $\mathrm{E}^{\circledR}$ showed the best performances, with mean Ct values ranging from $33.58 \pm 0.45$ to $37.47 \pm 3.20$, and from $33.71 \pm 0.62$ to $38.05 \pm 4.16$, respectively. Oppositely, Lysing Matrix $B^{\circledR}$ and Lysing Matrix $C^{\circledR}$ showed the lowest performances, with mean $C t$ values ranging from $35.23 \pm 1.34$ to $42.25 \pm 3.81$, and from $35.67 \pm 2.54$ to $43.53 \pm 2.85$, respectively (Table 4 ). 
At the concentration of 100 oocysts / mL, two mechanical lysing matrixes stood out from the others: (i) Lysing Matrix $D^{\circledR}$, which displayed $C t$ values statistically lower than those obtained with Lysing Matrixes $\mathrm{B}^{\circledR}, \mathrm{C}^{\circledR}, \mathrm{F}^{\circledR}, \mathrm{H}^{\circledR}, \mathrm{I}^{\circledR}$, and $\mathrm{J}^{\circledR}$, and which also appeared to be more reproducible, with a lower dispersion of the $\mathrm{Ct}$, and (ii) Lysing Matrix $\mathrm{E}^{\circledR}$, which showed $\mathrm{Ct}$ values statistically lower than those obtained with Lysing Matrixes $\mathrm{B}^{\circledR}, \mathrm{C}^{\circledR}$, and $\mathrm{H}^{\circledR}$ (Figure $2 \mathrm{~A}$ and Table S2).
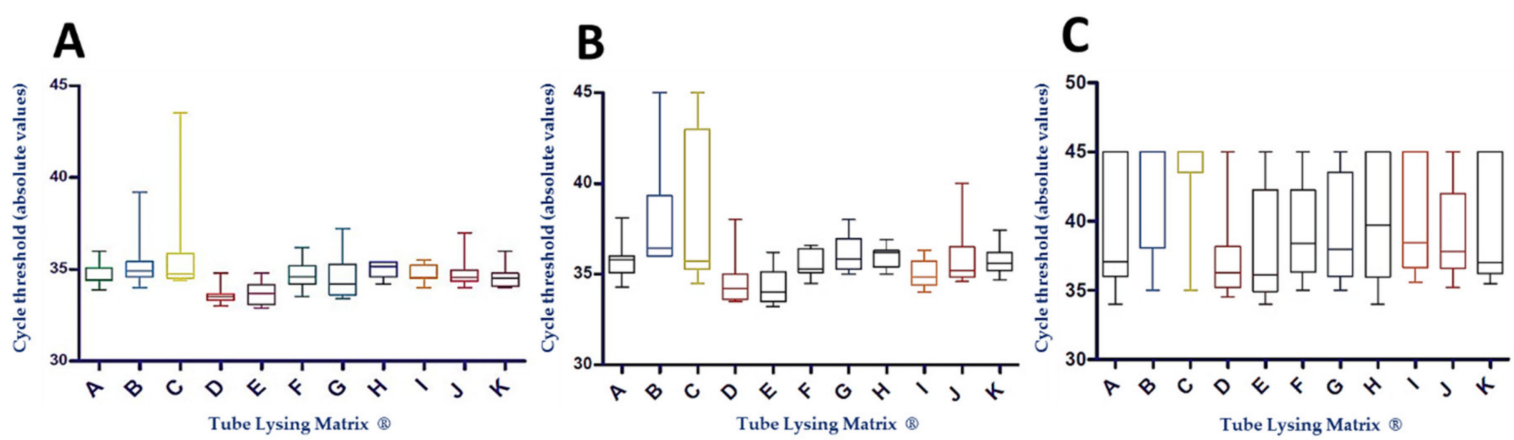

Figure 2. Distribution of the $\mathrm{Ct}$ results obtained according to the mechanical lysing matrix at the concentration of (A) 100 oocysts $/ \mathrm{mL}$, (B) 50 oocysts $/ \mathrm{mL}$, and (C) 20 oocysts $/ \mathrm{mL}$.

At the concentration of 50 oocysts $/ \mathrm{mL}$, Lysing Matrix $\mathrm{B}^{\circledR}$ exhibited the worst performances, with $\mathrm{Ct}$ values significantly higher than those obtained with Lysing Matrixes $\mathrm{D}^{\circledR}$, $\mathrm{E}^{\circledR}$, and $\mathrm{I}^{\circledR}$, while Lysing Matrix $\mathrm{E}^{\circledR}$ showed the best results, with $\mathrm{Ct}$ values significantly lower than those obtained with Lysing Matrixes $\mathrm{B}^{\circledR}, \mathrm{C}^{\circledR}, \mathrm{G}^{\circledR}$, and $\mathrm{H}^{\circledR}$. Furthermore, Lysing Matrix $\mathrm{C}^{\circledR}$ showed a greater dispersion of results than the others (Figure 2B and Table S3).

At the lower concentration of 20 oocysts $/ \mathrm{mL}$, Lysing Matrix $\mathrm{D}^{\circledR}$ and Lysing Matrix $\mathrm{E}^{\circledR}$ showed higher rates of DNA extraction and amplification, linked to lower Ct values. A significant difference was observed between the $C t$ values for Lysing Matrix $\mathrm{D}^{\circledR}$ and Lysing Matrix $\mathrm{E}^{\circledR}$ and those of Lysing Matrix $\mathrm{B}^{\circledR}$ and Lysing Matrix $\mathrm{C}^{\circledR}$. Finally, Lysing Matrix $C^{\circledR}$ showed poorer performances, with $C$ t values significantly higher than those of Lysing Matrixes $A^{\circledR}, D^{\circledR}, E^{\circledR}, F^{\circledR}, G^{\circledR}, J^{\circledR}$, and $K^{\circledR}$ (Figure $2 C$ and Table S4).

\section{Discussion}

Recently, our team highlighted the importance of sample pretreatment, as well as the extraction method, on the diagnostic performances of the C. parvum DNA amplification methods [20]. In this context, and in order to go further in the improvement of the C. parvum DNA amplification methods, we focused this complementary study on the evaluation of the impact of the mechanical lysing matrix used for the pretreatment of stool samples for PCR detection of Cryptosporidium DNA. The eleven Lysis Matrixes ${ }^{\circledR}$ (MP Biomedical ${ }^{\circledR}$ ) included in this study showed variable performances, dispatched into three distinct groups: (1) including Lysis Matrixes $B^{\circledR}$ and $C^{\circledR}$, which had the lowest performances for C. parvum DNA extraction and amplification, (2) gathering Lysis Matrixes $\mathrm{A}^{\circledR}, \mathrm{F}^{\circledR}, \mathrm{G}^{\circledR}, \mathrm{H}^{\circledR}, \mathrm{I}^{\circledR}, \mathrm{J}^{\circledR}$, and $\mathrm{K}^{\circledR}$, which showed comparable intermediate efficiency, and (3) including Lysis Matrixes $\mathrm{E}^{\circledR}$ and $\mathrm{D}^{\circledR}$, which achieved the best performances for $C$. parvum DNA amplification. It is interesting to note that the only matrix indicated (Lysing Matrix $\mathrm{B}^{\circledR}$ ) by the manufacturer for oocysts pretreatment is one of the matrixes with the poorest performance, hence the importance of this type of study.

Thus, our data corroborate the view that the characteristics of the beads used in lysis matrixes, including bead size, shape, and molecular composition, influence the performances of the pretreatment step (Figure 3). 


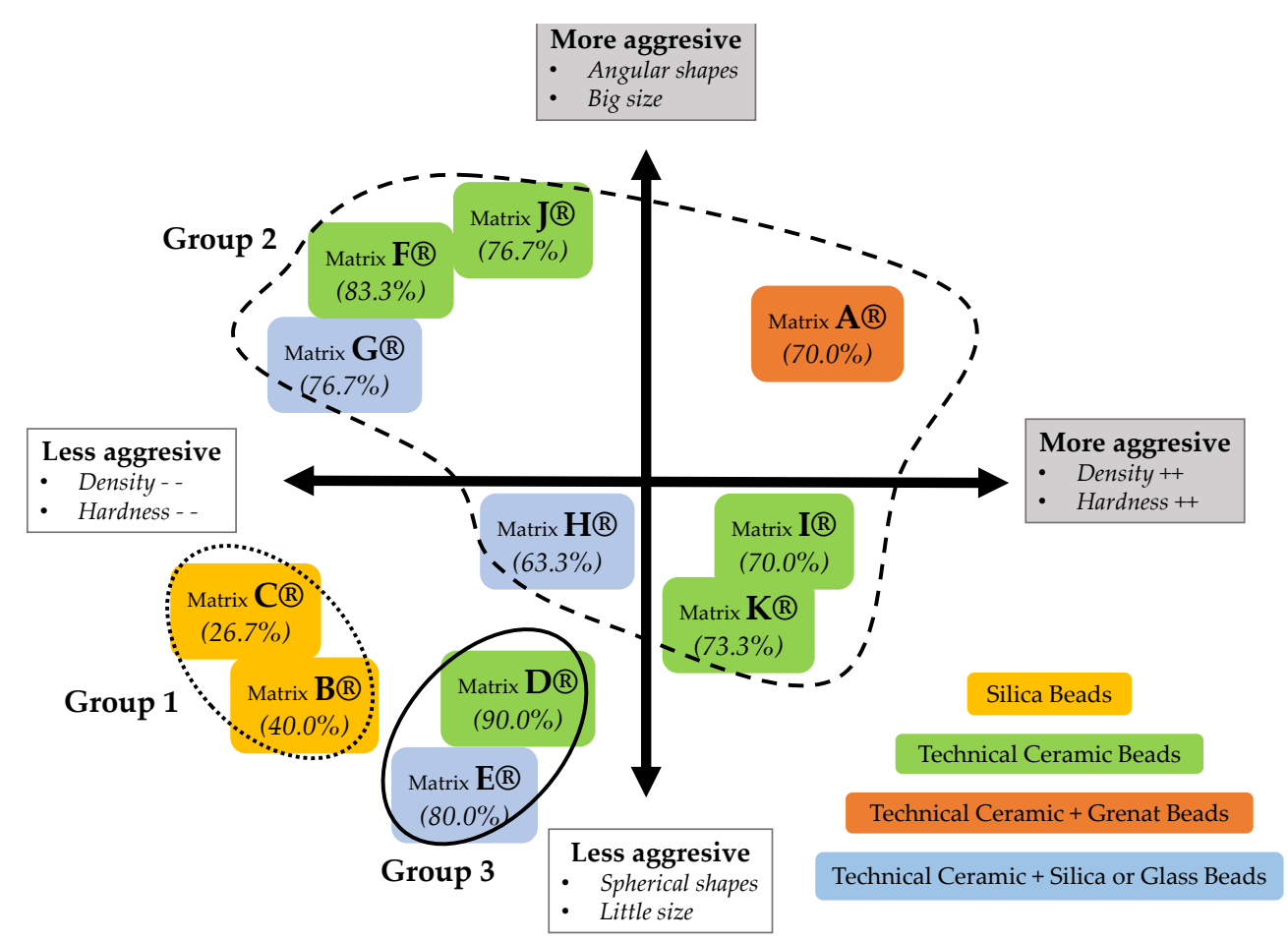

Figure 3. Repartition of the eleven mechanical lysing matrixes according to their characteristics and performances (percentage of detection at the concentration of 20 oocysts $/ \mathrm{mL}$ ).

Globally, the results obtained for the three groups of components tested during this study are consistent with those observed in our previous study [20]. Thus, the technical ceramic matrixes were the most efficient, particularly when used alone. Conversely, the glass or silica beads presented the worse performances used alone, and also showed a negative impact in combination with other components by reducing the overall performances. Moreover, we highlighted that shape and chemical composition are closely linked. Therefore, the same chemical nature and spherical shape, leading to mechanical lysis by crushing forces, seems to present better performance for C. parvum oocysts DNA extraction than angular shape, carrying out lysis by shear forces. Thus, aggressive pretreatment could result in a decrease in the overall extraction performances. Indeed, mechanical pretreatment could induce either a Cryptosporidium sp. DNA alteration or simply doesn't allow expulsion of Cryptosporidium sp. DNA from the oocyst. Furthermore, as previously reported, the use of smaller beads seems to be efficient for the lysis of small structures, such as oocysts. Indeed, in the case of the extraction and excystation of oocysts of Eimeria sp., it has been shown that the use of small glass beads $(0.5 \mathrm{~mm})$ effectively broke the wall of oocysts, while larger ones preserved sporozoites [21,23].

All in all, the molecular composition, shape, and size of the particles of the lysis matrix influence the extraction performance by determining two essential qualities for the grinding step: hardness and density. Indeed, the constituent elements of the lysis matrix need to combine (i) a hardness greater than that of the wall of the oocyst, and (ii) a density close to the buffer used during the pretreatment, so that the beads do not float, aimed at efficiently disrupting oocysts for Cryptosporidium sp. DNA extraction [11,21,23]. However, as demonstrated in our previous study, the use of glass beads for the pretreatment step will result in variable performances, depending on the extraction protocol used [20]. Thus, it is important to consider the pretreatment step in association with the extraction method.

\section{Conclusions}

Nowadays, many commercial kits allow the detection of Cryptosporidium sp. DNA in stool specimens, but the complex physicochemical features of the Cryptosporidium sp. oocyst wall require optimization and standardization of the extraction protocols. We previously 
highlighted the importance of sample pretreatment, as well as the extraction method, to improve the diagnostic performances of the C. parvum DNA amplification methods. Here, in this complementary study, we showed the importance of beads' physicochemical characteristics on the success of the pretreatment step, particularly the shape and chemical composition, which are closely related.

Supplementary Materials: The following are available online at https:/ /www.mdpi.com/2076-260 7/9/2/297/s1, Table S1: Degrees of statistical significance of Chi2 tests comparing the percentage of positive Cryptosporidium parvum PCR according to the mechanical lysis matrix used for the concentrations of 20 oocysts/mL; Table S2: Degrees of statistical significance of Mann-Whitney tests comparing mean $\mathrm{Ct}$ values of Cryptosporidium parvum PCRs according to mechanical lysing matrix for the concentrations of 100 oocysts/mL., Table S3: Degrees of statistical significance of Mann-Whitney tests comparing mean $\mathrm{Ct}$ values of Cryptosporidium parvum PCRs according to mechanical lysing matrix for the concentration of 50 oocysts/mL., Table S4: Degrees of statistical significance of MannWhitney tests comparing mean Ct values of Cryptosporidium parvum PCR according to mechanical lysing matrix for the concentrations of 20 oocysts $/ \mathrm{mL}$

Author Contributions: Conceptualization, F.D. and N.V.; methodology, F.D., S.V. and N.V.; formal analysis, B.P., L.B. and L.C.; resources, L.F., F.D., D.C., S.V., L.B. and A.V.; writing-original draft preparation, L.B., L.C. and N.V.; writing-review and editing, L.C., L.B., N.V., S.V. and F.D.; visualization, L.C.; supervision, F.D. and N.V. All authors have read and agreed to the published version of the manuscript.

Funding: This research was funded by Sante Publique France.

Institutional Review Board Statement: Not applicable.

Informed Consent Statement: Not applicable.

Acknowledgments: The authors gratefully thank Sante Publique France for their funding of CNR-LE cryptosporidiosis activities.

Conflicts of Interest: The authors declare no conflict of interest. The funders had no role in the design of the study; in the collection, analyses, or interpretation of data; in the writing of the manuscript, or in the decision to publish the results.

\section{References}

1. Checkley, W.; White, A.C.; Jaganath, D.; Arrowood, M.J.; Chalmers, R.M.; Chen, X.M.; Fayer, R.; Griffiths, J.K.; Guerrant, R.L.; Hedstrom, L.; et al. A review of the global burden, novel diagnostics, therapeutics, and vaccine targets for Cryptosporidium. Lancet Infect. Dis. 2015, 15, 85-94. [CrossRef]

2. Benamrouz-Vanneste, S.; Sawant, M.; Benamrouz, S.; Chabé, M.; Guyot, K.; Costa, D.; Favennec, L.; Gargala, G.; Viscogliosi, E.; Certad, G. La cryptosporidiose et son impact en santé publique. Rev. Biol. Med. 2020, hal02400544.

3. Costa, D.; Razakandrainibe, R.; Valot, S.; Vannier, M.; Sautour, M.; Basmaciyan, L.; Gargala, G.; Viller, V.; Lemeteil, D.; Ballet, J.J. Epidemiology of Cryptosporidiosis in France from 2017 to 2019. Microorganisms 2020, 8, 1358. [CrossRef] [PubMed]

4. Gerace, E.; Di Marco, V.; Biondo, C. Cryptosporidium Infection: Epidemiology, Pathogenesis, and Differential Diagnosis. Eur. J. Clin. Microbiol. Immunol. 2019, 9, 119-123. [CrossRef] [PubMed]

5. Arya, M.; Shergill, I.S.; Williamson, M.; Gommersall, L.; Arya, N.; Patel, H.R.H. Basic principles of real-time quantitative PCR. Expert Rev. Mol. Diagn. 2005, 5, 209-219. [CrossRef]

6. Autier, B.; Belaz, S.; Razakandrainibe, R.; Gangneux, J.P.; Robert-Gangneux, F. Comparison of three commercial multiplex PCR assays for the diagnosis of intestinal protozoa. Parasite 2018, 25, 48. [CrossRef]

7. Autier, B.; Gangneux, J.P.; Robert-Gangneux, F. Evaluation of the Allplex ${ }^{\mathrm{TM}}$ gastrointestinal panel-Parasite assay for protozoa detection in stool samples: A retrospective and prospective study. Microorganisms 2020, 8, 569. [CrossRef]

8. Morio, F.; Poirier, P.; Le Govic, Y.; Laude, A.; Valot, S.; Desoubeaux, G.; Argy, N.; Nourrisson, C.; Pomares, C.; Machouart, M.; et al. Assessment of the first commercial multiplex PCR kit (ParaGENIE Crypto-Micro Real-Time PCR) for the detection of Cryptosporidium spp., Enterocytozoon bieneusi, and Encephalitozoon intestinalis from fecal samples. Diagn. Microbiol. Infect. Dis. 2019, 95, 34-37. [CrossRef]

9. Mary, C.; Chapey, E.; Dutoit, E.; Guyot, K.; Hasseine, L.; Jeddi, F.; Menotti, J.; Paraud, C.; Pomares, C.; Rabodonirina, M.; et al. Multicentric evaluation of a new real-time PCR assay for quantification of Cryptosporidium spp. and identification of Cryptosporidium parvum and Cryptosporidium hominis. J. Clin. Microbiol. 2013, 51, 2556-2563. [CrossRef]

10. Jeddi, F.; Piarroux, R.; Mary, C. Application of the NucliSens easyMAG system for nucleic acid extraction: Optimization of DNA extraction for molecular diagnosis of parasitic and fungal diseases. Parasite 2013, 20, 52. [CrossRef] 
11. Le Govic, Y.; Guyot, K.; Certad, G.; Deschildre, A.; Novo, R.; Mary, C.; Sendid, B.; Viscogliosi, E.; Favennec, L.; Dei-Cas, E. Assessment of microscopic and molecular tools for the diagnosis and follow-up of cryptosporidiosis in patients at risk. Eur. J. Clin. Microbiol. Infect. Dis. 2016, 35, 137-148. [CrossRef] [PubMed]

12. Paulos, S.; Marta, M.; De Lucio, A.; Hernandez-de Mingo, M.; Bailo, B.; Saugar, J.M.; Cardona, G.A.; Fuentes, I.; Mateo, M.; Carmena, D. Evaluation of five commercial methods for the extraction and purification of DNA from human faecal samples for downstream molecular detection of the enteric protozoan parasites Cryptosporidium spp., Giardia duodenalis, and Entamoeba spp. J. Microbiol. Methods 2016, 127, 68-73. [CrossRef] [PubMed]

13. Menu, E.; Mary, E.; Toga, I.; Raoult, D.; Ranque, S.; Bittar, F. Evaluation of two DNA extraction methods for the PCR-based detection of eukaryotic enteric pathogens in fecal samples. BMC Res. Notes 2018, 11, 206. [CrossRef] [PubMed]

14. Shields, J.M.; Joo, J. Assessment of three commercial DNA extraction kits and a laboratory-developed method for detecting Cryptosporidium and Cyclospora in raspberry wash, basil wash and pesto. J. Microbiol. Methods 2013, 95, 51-58. [CrossRef] [PubMed]

15. Samuelson, J.; Bushkin, G.G.; Chatterjee, A.; Robbins, P.W. Strategies to discover the structural components of cyst and oocyst walls. Eukaryot. Cell 2013, 12, 1578-1587. [CrossRef]

16. Lendner, M.; Daugschies, A. Cryptosporidium infections: Molecular advances. Parasitology 2014, 141, 511-532. [CrossRef]

17. Headd, B.; Bradford, S.A. Use of aerobic spores as a surrogate for Cryptosporidium oocysts in drinking water supplies. Water Res. 2016, 90, 185-202. [CrossRef]

18. Nichols, R.A.B.; Smith, H.V. Optimization of DNA extraction and molecular detection of Cryptosporidium oocysts in natural mineral water sources. J. Food Prot. 2004, 67, 524-532. [CrossRef]

19. Halstead, F.D.; Lee, A.V.; Couto-Parada, X.; Polley, S.D.; Ling, C.; Jenkins, C.; Chalmers, R.M.; Elwin, K.; Gray, J.J.; Iturriza-Gomara, M.; et al. Universal extraction method for gastrointestinal pathogens. J. Med. Microbiol. 2013, 62, 1535-1539. [CrossRef]

20. Valeix, N.; Costa, D.; Basmaciyan, L.; Valot, S.; Vincent, A.; Razakandrainibe, R.; Robert-Gangneux, F.; Nourrisson, C.; Pereira, B.; Fréalle, E. Multicenter comparative study of six Cryptosporidium parvum DNA extraction protocols including mechanical pretreatment from stool samples. Microorganisms 2020, 8, 1450. [CrossRef]

21. Cha, J.O.; Talha, A.F.S.M.; Lim, C.W.; Kim, B. Effects of glass bead size, vortexing speed and duration on Eimeria acervulina oocyst excystation. Exp. Parasitol. 2014, 138, 18-24. [CrossRef] [PubMed]

22. Brunet, J.; Lemoine, J.P.; Pesson, B.; Valot, S.; Sautour, M.; Dalle, F.; Muller, C.; Borni-Duval, C.; Caillard, S.; Moulin, B.; et al. Ruling out nosocomial transmission of Cryptosporidium in a renal transplantation unit: Case report. BMC Infect. Dis. 2016, 16, 363. [CrossRef] [PubMed]

23. You, M.J. Effects of different sizes of glass beads on the release of sporocysts from Eimeria tenella oocysts. Korean J. Parasitol. 2014, 52, 317-319. [CrossRef] [PubMed] 